\title{
CHEMICAL RESPONSE OF MAIZE PLANTS TO FALL ARMYWORM FEEDING DAMAGE
}

\author{
YURI MACHADO ${ }^{1}$, JACQUELINE APARECIDA TAKAHASHI ${ }^{1}$, \\ PAULO AFONSO VIANA², PAULO EDUARDO DE AQUINO RIBEIRO \\ AND PAULO EVARISTO DE OLIVEIRA GUIMARÃES ${ }^{2}$
}

${ }^{1} U F M G$, Belo Horizonte, MG, Brasil,yurimachad@gmail.com,jat@qui.ufmg.br

${ }^{2}$ Embrapa Milho e Sorgo, Sete Lagoas, MG, Brasil, paulo.viana@embrapa.br, paulo.eduardo@embrapa.br, paulo.guimaraes@embrapa.br

$\overline{R e v i s t a ~ B r a s i l e i r a ~ d e ~ M i l h o ~ e ~ S o r g o, ~ v .13, ~ n .3, ~ p . ~ 249-260, ~} 2014$

\begin{abstract}
This work aimed at verifying the chemical response to Spodotera frugiperda associated to some selected genotypes resistant to this fall armyworm, subsidizing studies for improving commercial cultivars. Genotypes were grown and divided into two groups: a group was infested with $S$. frugiperda and another group was not infested (control). Extracts from plants of both groups were prepared and their chromatographic profiles were obtained by high performance liquid chromatography. Chlorogenic acid, described in the literature as a natural metabolite with food deterrent activity, was identified in some extracts by comparison with the authentic standard and, later, by mass spectrometry. The chromatograms obtained were classified using chemometric methods. The majority of the genotypes studied showed reduction in the concentration of chlorogenic acid when they were infested by the insect. In addition, extracts of some infested plants showed good activity against $S$. frugiperda, indicating the synthesis of one or more bioactive substances. This change in the metabolic profile was evidenced by statistical analysis, where pairs of controlinfested genotypes were distinct from each other. The results point that interaction between insect and plant impacted on the production of metabolites by the plant.
\end{abstract}

Key words: HPLC; chlorogenic acid; Zea mays; Spodoptera frugiperda.

\section{RESPOSTA QUímiCA DE PLANTAS DE MILHO À LAGARTA-DO-CARTUCHO DEVIDO A DANOS ALIMENTARES}

RESUMO - Este trabalho teve como objetivo verificar a resposta química a Spodotera frugiperda associada a diversos genótipos selecionados com fonte de resistência a esta lagarta, subsidiando estudos para a melhoria dos cultivares comerciais. Os genótipos foram cultivados e divididos em dois grupos: uma parcela infestada com S. frugiperda e uma não infestada (controle). Extratos de plantas de ambos os grupos foram preparados e os seus perfis cromatográficos foram obtidos por cromatografia líquida de alta eficiência. O ácido clorogênico, descrito na literatura como metabólito natural com atividade de deterrência alimentar, foi identificado em alguns extratos por comparação com o padrão autêntico e, mais tarde, por espectrometria de massas. Os cromatogramas obtidos foram classificados por métodos quimiométricos. A maioria dos genótipos estudados apresentou redução da concentração de ácido clorogênico quando eles foram infestados pelo inseto. Além disso, os extratos de algumas plantas infestadas mostraram boa atividade contra $S$. frugiperda, indicando a síntese de uma ou mais substâncias bioativas. Esta mudança no perfil metabólico foi indicada na análise estatística, em que pares de controle infestados de genótipos eram distintos um do outro. Os resultados apontam que a interação entre insetos e planta induziu a produção de metabólitos pela planta.

Palavras-chave: CLAE; ácido clorogênico; Zea mays; Spodoptera frugiperda. 
Maize (Zea mays L.) has been used as food for millennia, showing high commercial value worldwide (Australian Government, 2008). Nowadays Brazil is the third biggest producer of maize in the world (Rocha et al., 2011). Analysis of several factors that contribute to downfalls has been resulting in increased productivity. Fall armyworm (Spodoptera frugiperda J. E. Smith) is the main pest affecting maize production (Sousa et al., 2011) in Brazil (Nagoshi et al., 2007), causing estimated losses of about $20 \%$.. Without control it can affect up to $73 \%$ of the production (Arias et al., 2011) which represents, losses up to 500 million dollars annually (Sá et al., 2009).

Fall armyworm affects several crops, including maize, cotton (Gossypium hirsutum L), rice (Oryza sativa L.), sorghum (Sorghum bicolor L. Moench), barley (Hordeum vulgare L.), tobacco (Nicotiana tabacum L.) and wheat (Triticum spp.) (Capinera, 2008). It is a major insect pest in maize crop in Brazil, since cause significant damages and is very difficult to control (Santos et al., 2004).

A method to control the fall armyworm is through the use of insecticides. However, this method presents some problems, such as the risk of environmental contamination and high costs due to problems with application technology because is difficult to reach the fall armyworm inside maize whorl (Cunha et al., 2008). In addition, the use of insecticides to control fall armyworm can result in serious problems such as presence of residual compounds in the food, elimination of natural competitors, environmental contamination and selection of insects resistant to insecticide (Negrisoli Jr et al., 2010).

Another method to control lepidoptera is the use of Bt maize, a genetically modified plant that contains a gene from Bacillus tungiensis responsible for the production of Cry proteins by the plant. Bt maize is cultivated nowadays in approximately six million hectares in 16 countries (Van der Berg et al., 2013).

Cultivars with desirable agronomic characteristics like pest resistance can be used as an alternative to the conventional pest management, especially because insect-resistant plants are welcome due to their biological and environmental advantages (Farinelli \& Fornasieri, 2006). Insects can be directly affected by plant secondary metabolites (Jourdie et al., 2010).

Chlorogenic acid can contribute to the resistance to $S$. frugiperda (Brooks et al., 2007). This compound presents antioxidant activity and protective effects against DNA damage (Xu et. al., 2012). It has also been reported the synergism between entomopathogens and secondary metabolites. In tomatoes, peroxidase and chlorogenic acid increased the toxicity of Bacillus thuringiensis kurskaki against cabbage looper Trichoplusia ni (Ibanez et al., 2012).

The resistance of maize to $S$. frugiperda has been intensively investigated (Silva et al., 2000; Sá et al., 2009). Stout et al. (2009) conducted a study comparing the pathways of plant response with the larvae development, and verified the existence of an induced resistance in rice when attacked by the pest.

Silveira et al. (1997) evaluated the resistance of various maize genotypes to $S$. frugiperda, concluding that Mp707 and Zapalote Chico were the most resistant genotypes to the fall armyworm. Silva et al. (2000) and Lima et al. (2008) tried to identify sources of resistance to S. frugiperda. According to Silva et al. (2000), parameters like level of damage to the plant, weight and length of the caterpillars can be used to determine the level of resistance of the crop genotypes. 
Viana \& Potenza (2000) reported the identification of the mechanisms of genotype resistance, antibiosis and non-preference factors in maize to $S$. frugiperda. Waquil et al. (2002) evaluated the resistance of transgenic Bt maize expressing genes of Bacillus thuringiensis toxin producers against larvae.. In both cases, in general, multiple genotypes tested showed some level of resistance.

The present study aimed to evaluate the chemical response to Spodotera frugiperda associated with some selected genotypes resistant to this fall armyworm, subsidizing studies for the improvement of commercial cultivars.

\section{Material and Methods}

Maize genotypes used in this work were LCMS23-23, LCMS23-21B, MIRT-2Q, LMIRT2Q, HSCMS23-6LCMS2323 X LCMS23-21B, HSMIRT4LMRT2A X LMIRT20B, L3 and Zapalote Chico(G1, G2, G3, G4, G5, G6, G7 and G8, respectively). Seeds were obtained from Embrapa breeding program. The genotypes, with the exception of L3 and Zapalote Chico, are hybrids and lineages with some degree of resistance to $S$. frugiperda through genetic breeding (Viana \& Potenza, 2000; Costa et al., 2006).

The plants were grown on a greenhouse located in the Embrapa Maize and Sorghum (Sete Lagoas, Brazil) in November, 2008. The experiment used a random blocks designed. Eight maize genotypes were used and for each genotype eight pots containing five plants each were used, totaling 320 plants and 40 plants per cultivar. NPK 8/28/16 fertilized soil (300 $\left.\mathrm{kg} \mathrm{ha}^{-1}\right)$ was added to the pots. Half of the plants from each genotype were infested with hatched S. frugiperda caterpillars and the other half was preserved as control.
The leaves used in the work were chosen randomly from each pot. The plant material was stored under low temperature for transportation and stored under refrigeration for conservation until being processed. The leaves were collected, superficially cleaned with distilled water, dried, weighed and manually grinded using liquid nitrogen.

The grinded material was transferred to a beaker and HPLC-grade methanol was added to complete the volume to $200 \mathrm{ml}$. The contents were subjected to heating (below methanol boiling temperature) under stirring, for $20 \mathrm{~min}$ and then filtered with a filter paper. The residue was washed with HPLC-grade methanol $(50 \mathrm{ml})$, the solvent was evaporated down and the extract was quantitatively transferred to a vial. The samples were stored under refrigeration until the moment of analysis. The samples were filtered prior to HPLC analysis using Millex LCR 0.45 filter units.

HPLC analyses were performed on a Shimadzu LC10AD series Liquid Chromatograph coupled to a SPDM10avp LC10AD Photo Diode Array detector (PDA), operating with two pumps and a SIL 10AF auto-injector, CBM10A module, equipped with a C-18 column (25 cm x $4.6 \mathrm{~mm}$, Supelco), with particle size equal to $5 \mu \mathrm{m}$. SPDMXA Post Run Analysis software was used. Chromatograms at wavelengths 280 and $320 \mathrm{~nm}$ were obtained.

The method was optimized to use a gradient consisting of a mixture of two solutions as the mobile phase. The solution A contained phosphoric acid aqueous solution $(0.2 \% \mathrm{v} / \mathrm{v})$ and the solution B was composed by HPLC-grade acetonitrile and phosphoric acid $(0.2 \% \mathrm{v} / \mathrm{v})$. The following schedule was used: from 0 to $65 \mathrm{~min}$, we departed from $10 \%$ to $25 \%$ of solution B. From 65 to $67 \mathrm{~min}$, amount of solution B increased from $25 \%$ up to $99 \%$, keeping 
isocratic at this concentration ( $99 \%$ of solution B) up to $73 \mathrm{~min}$. For rebalancing the column, the initial concentration was reestablished from 73 to $75 \mathrm{~min}$, decreasing from $99 \%$ to $10 \%$ of solution B, keeping at this concentration from 75 to $90 \mathrm{~min}$. The solvent

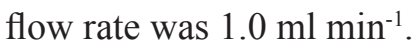

All maize extracts, infested and non infested, were analyzed by high performance liquid chromatography and their profiles were compared with profiles of standard compound (chlorogenic acid) through the comparison of their retention times and ultraviolet spectra. Therefore, a standard solution of this compound was co-injected with the extracts.

Solutions with concentrations of 60,50 , 40, 30, 20, 10 and $2 \mu \mathrm{g} \mathrm{ml}^{-1}$ were used to obtain a calibration curve for chlorogenic acid using the same method previously described. The solutions were analyzed in triplicate. The data relative to the areas under chlorogenic acid peaks, extracted from the chromatograms using LC10 Class, software used by the chromatograph, were utilized to obtain the calibration curve. Using the equation obtained from the calibration curve and chlorogenic acid related areas in the chromatograms of the extracts, the dried extract weight and the leaf weight, the concentrations of chlorogenic acid present in leaf tissues of each genotype were determined. For comparing variation of chlorogenic acid levels among the genotypes t-test at $5 \%$ significance was used.

The LCMS analysis was performed on a Liquid Chromatograph coupled to a Esquire 3000 Plus (Bruker Daltonics) Mass Spectrometer, equipped with C-18 column (Luna Phenomenex, $25 \mathrm{~cm} \mathrm{x}$ $4.6 \mathrm{~mm}$ ), with particle size equal to $5 \mu \mathrm{m}$, capillary voltage $4000 \mathrm{~V}$, capillary temperature $320^{\circ} \mathrm{C}$, positive mode, gas flow $7.01 \mathrm{~min}^{-1}$, pressure of 28 psi, flow to mass of $100 \mu \mathrm{min}^{-1}$. The method used was the same as described previously for the determination of chlorogenic acid.

Eight plastic trays containing each one eight blocks of sixteen cells were used. Modified Reese diet (Viana \& Guimarães, 1997) was prepared, and $1 \mathrm{ml}$ was added to each cell. The test was planned on a way that each cell contained $15 \mathrm{mg}$ of the plant extract. Replicates were carried out, except on a few cases (G4 and G6 infested), due to the low amounts obtained.

The extracts were dissolved using methanol as solvent and applied three times (10 $\mu$ l each application) in the dietary blocks, with interval of 10 min among the applications for solvent evaporation. A control was carried out applying only the solvent (methanol) in some of the dietary blocks. In other blocks, it was not added solvent or extracts, in order to detect eventual interferences of the solvent used. After the addition of extracts and solvent, the trays were transferred to a room with controlled temperature (27 $\pm 1{ }^{\circ} \mathrm{C}$ ), in order to assure the complete evaporation of the solvent.

On the following day, just hatched larvae were placed in each cell. The experiment was conducted by seven days, weight (mg) and encephalic capsule size $(\mathrm{mm})$ were measured and these parameters were used to evaluate the antibiosis in the caterpillars (Viana \& Potenza, 2000). The mass of uneaten dietary was also evaluated. In this case, faeces were eliminated using a small brush. The data were statistically analyzed using the SAS software. Mean values were compared using t-test at 5\%.significance.

Principal Component Analysis (PCA) and Hierarchical Cluster Analysis (HCA) were carried out using the applicative Statistica 6.0 in order to make a statistical analysis of the chromatograms similarity. To accomplish this, the chromatograms of the 
extracts were converted into text files, using the fixed wavelength of $320 \mathrm{~nm}$ as the absorbance data source, since this was the wavelength used throughout all the analyses. The columns related to the retention times and the absorbance values in this selected wavelength were transferred to the Statistica 6.0 applicative. Then, mean values of each set were obtained and there were generated graphics using PCA and HCA. Later, it was constructed a classification of the chromatograms extracts, aiming to show the most similar ones in terms of their chemical constitutions.

\section{Results and Discussion}

Figure 1 shows an example of chromatogram obtained for G1, infested (a) and non-infested (b). All standards were also profiled by HPLC and chlorogenic acid was found to be the most recurrent compound in the extracts among the available standards. The analysis of chromatograms extracts along with the chromatograms generated through co-injection, confirmed the presence of chlorogenic acid in the extracts, except in extract G8 non-infested.

The average of the area under the peaks was used to build the calibration curve, as can be observed in Figure 2, described by the equation obtained by linear regression:

$\mathrm{y}=58719.394 \mathrm{x}-31191.9700 \quad$ (squared linearity coefficient $\left.r^{2}=0.9992\right)$.

The concentration of chlorogenic acid in maize leaves can be found in Table 1. When $p$ value found was greater than 0.05 , it was considered that there was no statistical difference between the pair infested - not infested plant. In this way, statistically significant differences were detected in the concentration of chlorogenic acid between all pairs of non-infested/infested plants, except for G2. Significant differences were also found between different genotypes in the same treatment.

TABLE 1. Chlorogenic acid levels in the maize leaves, percentages and $\mathrm{p}$ values, as determined by t-test, at $5 \%$ significance of maize extracts from non-infested and infested genotypes.

\begin{tabular}{|c|c|c|c|c|}
\hline \multirow[t]{2}{*}{ Genotype } & \multicolumn{2}{|c|}{$\begin{array}{l}\text { Chorogenic acid/leaves } \\
\qquad\left(\mu \mathrm{g} \mathrm{g}^{-1}\right)\end{array}$} & \multirow{2}{*}{$\begin{array}{l}\text { Chlorogenic acid level } \\
\text { reduction/increment } \\
\text { after attack }(\%)^{1}\end{array}$} & \multirow[t]{2}{*}{$P$} \\
\hline & Non-infested & Infested & & \\
\hline LCMS23-23 & 92.60 & 56.04 & 39.4 & 0.000006 \\
\hline LCMS23-21B & 158.87 & 148.88 & 0 & 0.658110 \\
\hline MIRT-2Q & 16.85 & 7.63 & 54.7 & 0.000174 \\
\hline LMIRT-2Q & 101.45 & 84.24 & 17.0 & 0.000492 \\
\hline HSCMS23-6LCMS2323 X LCMS23-21B & 91.47 & 27.96 & 69.4 & 0.000000 \\
\hline HSMIRT4LMRT2A X LMIRT20B & 44.23 & 14.19 & 44.2 & 0.006837 \\
\hline L3 & 31.26 & 37.87 & -21.1 & 0.000002 \\
\hline
\end{tabular}

${ }^{1}$ Negative value means increase in the values found for the acid. 

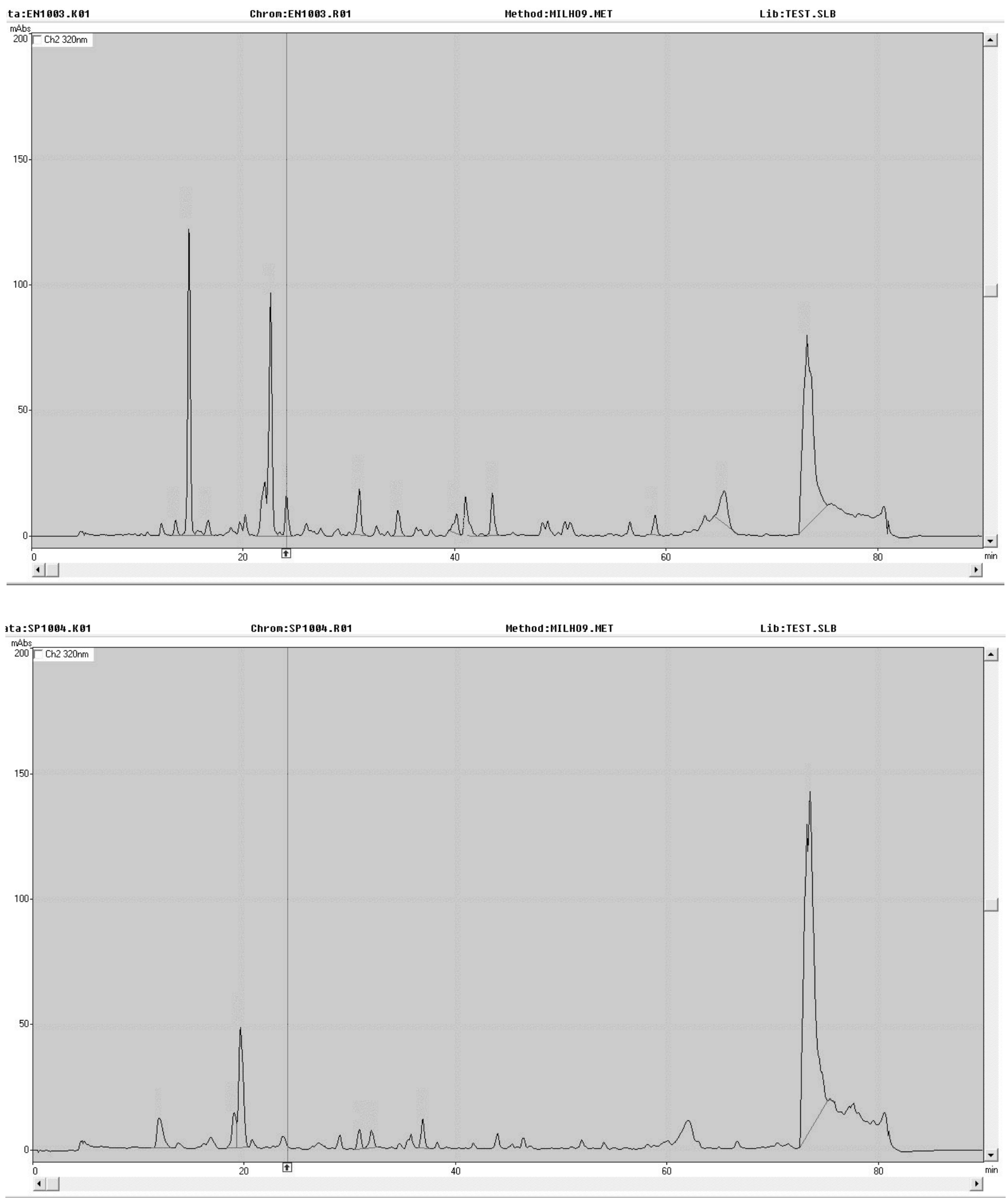

FIGURE 1. Chromatograms obtained for non-infested (a) and infested (b) G1 plants. 
After statistical evaluation, variation of chlorogenic acid in extracts of different genotypes was studied. The difference between infested and non-infested G2 was not considered since the difference between them was not significant. Similar situation occurred for G8, since chlorogenic acid was not detected in the noninfested plants. It can be assumed that, with the exception of $\mathrm{G} 7$, a reduction of the chlorogenic acid concentration in the leaf tissues of infested plants occurred. The reduction was more pronounced for G5 and G3 that exceeded 50\% of reduction. In G7 there was increase of chlorogenic acid concentration after infestation. This tendency in the alteration of chlorogenic acid concentration may be related to a metabolic alteration of the plant.

In the LCMS analyses, a peak corresponding to chlorogenic acid $(\mathrm{m} / \mathrm{z} 354.9)$ was observed in the extracts obtained from infested and non-infested G1, non-infested and infested G5, and infested G6.

In relation to the biological assay, no significant difference between the uneaten dietary by $S$. frugiperda was observed. The interference of the solvent used for extraction (methanol) in the measurements was not significant, compared to the positive control. The mean values for larvae weight and width of their cephalic capsules are showed in Table 2. Regarding the other two parameters, significant differences at 5\% significance level were detected. Larvae fed with the extracts showed lower development compared to controls, indicating antibiosis. It was not observed relationship between toxicity and levels of chlorogenic acid in the plants.

Quantitatively, the extracts from G6 infested, G8 infested, G2 non-infested, G3 infested, and

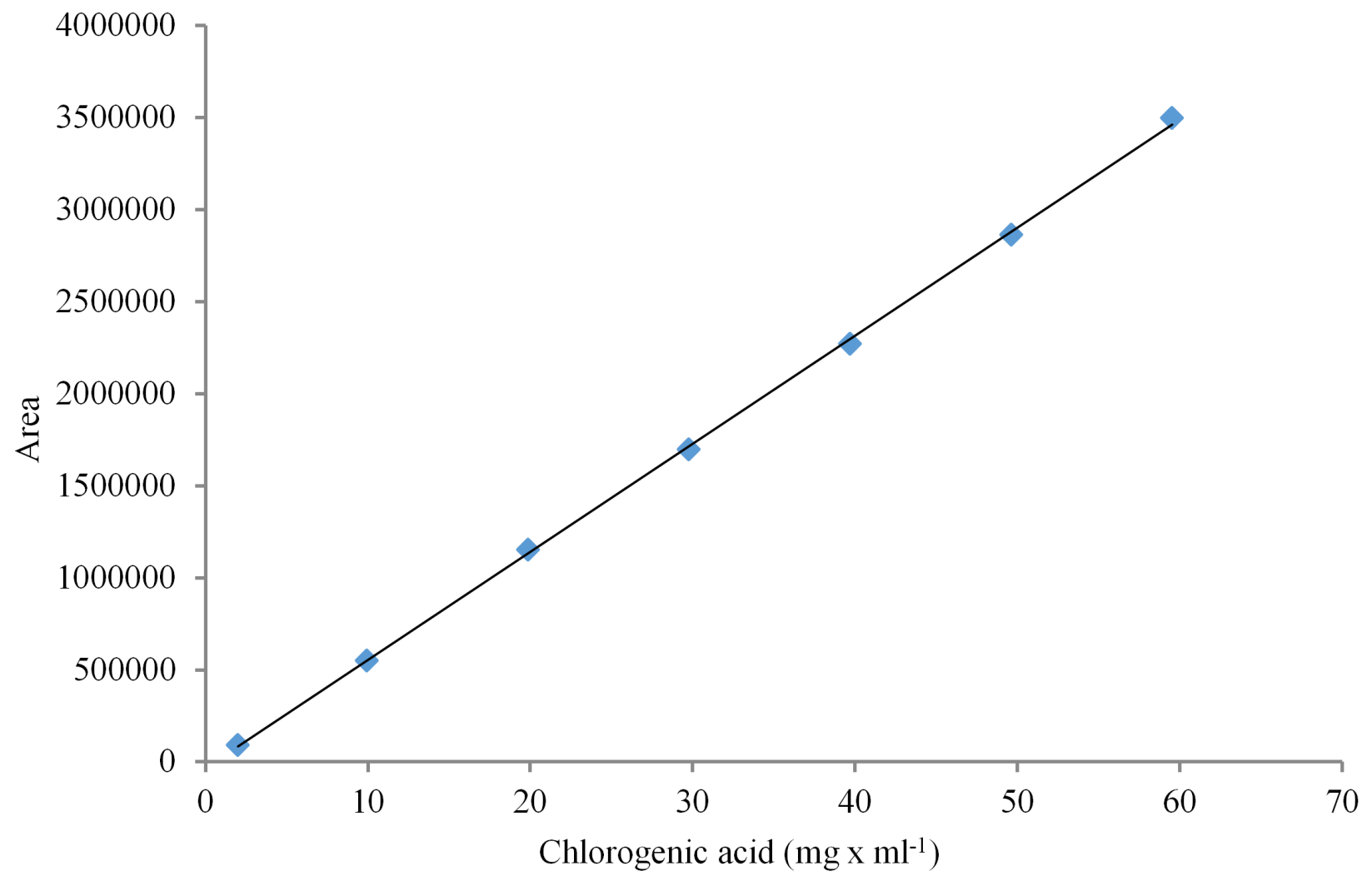

FIGURE 2. Calibration curve of the area under the chromatographic peak according to the concentration of chlorogenic acid. The area has no unit. 
TABLE 2. Mean values for weight and cephalic length of fall armyworm and respective t-test classification. ${ }^{1}$

\begin{tabular}{|c|c|c|c|}
\hline Genotype & $\begin{array}{l}\text { S. frugiper- } \\
\text { da weight } \\
(\mathrm{mg})\end{array}$ & Genotype & $\begin{array}{c}\text { S. } \\
\text { frugiperda } \\
\text { cephalic } \\
\text { length }(\mathrm{mm})\end{array}$ \\
\hline HSMIRT4LMRT2A X LMIRT20B (I)² & $46.0 \mathrm{G}$ & HSMIRT4LMRT2A X LMIRT20B (I) & $0.38 \mathrm{~F}$ \\
\hline Zapalote Chico (I) & $50.6 \mathrm{G}$ & MIRT-2Q (I) & $0.77 \mathrm{EF}$ \\
\hline $\mathrm{L} 3(\mathrm{NI})^{3}$ & $61.1 \mathrm{G}$ & Zapalote Chico (I) & $0.93 \mathrm{DEF}$ \\
\hline L3 (I) & $63.9 \mathrm{FG}$ & LCMS23-21B (NI) & $0.99 \mathrm{DEF}$ \\
\hline LCMS23-21B (NI) & $66.4 \mathrm{FG}$ & LCMS23-23 (NI) & $1.00 \mathrm{DEF}$ \\
\hline MIRT-2Q (I) & $67.9 \mathrm{EFG}$ & L3 (I) & $1.06 \mathrm{DEF}$ \\
\hline LCMS23-23 (NI) & $71.7 \mathrm{EFG}$ & L3 (NI) & $1.19 \mathrm{DE}$ \\
\hline HSCMS23-6LCMS2323 X LCMS23-21B (I) & 72.4 DEFG & LCMS23-21B (I) & $1.22 \mathrm{CDE}$ \\
\hline LCMS23-21B (I) & 79.6 CDEFG & LMIRT-2Q (NI) & $1.31 \mathrm{CD}$ \\
\hline HSMIRT4LMRT2A X LMIRT20B (NI) & 83.1 CDEFG & HSMIRT4LMRT2A X LMIRT20B (NI) & $1.32 \mathrm{CD}$ \\
\hline Zapalote Chico (NI) & 87.3 CDEFG & HSCMS23-6LCMS2323 X LCMS23-21B (I) & $1.36 \mathrm{BCD}$ \\
\hline MIRT-2Q (NI) & 100.4 CDEF & Zapalote Chico (NI) & $1.43 \mathrm{BCD}$ \\
\hline LMIRT-2Q (I) & 103.0 CDE & MIRT-2Q (NI) & $1.54 \mathrm{BCD}$ \\
\hline LMIRT-2Q (NI) & 103.4 CDE & LMIRT-2Q (I) & 1.57 ABCD \\
\hline $\begin{array}{l}\text { HSCMS23-6LCMS2323 X LCMS23-21B } \\
\text { (NI) }\end{array}$ & 106.3 CD & $\begin{array}{l}\text { HSCMS23-6LCMS2323 X LCMS23-21B } \\
\text { (NI) }\end{array}$ & 1.57 ABCD \\
\hline LCMS23-23 (I) & $109.3 \mathrm{BC}$ & LCMS23-23 (I) & $1.64 \mathrm{ABC}$ \\
\hline Methanol & $114.7 \mathrm{~B}$ & Methanol & $1.77 \mathrm{AB}$ \\
\hline Pos. control & $162.6 \mathrm{~A}$ & Pos. control & $2.04 \mathrm{~A}$ \\
\hline
\end{tabular}

${ }^{1}$ Negative value means increase in the values found for the acid. ${ }^{2}$ Infested. ${ }^{3}$ Non-Infested. 
G7 non-infested presented higher inhibition of the larvae development. On the other hand, extracts G3 non-infested, G4 infested, G4 non-infested, G5 noninfested and G1 infested were not able to promote a great inhibition of its development. Zapalote Chico (G8), has already been pointed by Silveira et al. (2007) a genotype resistant to $S$. frugiperda. It was observed a tendency of infested plant extracts promoting greater response than the non-infested plants. This corroborates that foliar damage caused by $S$. frugiperda interferes with plant secondary metabolism, triggering the production of substances with some degree of activity against fall armyworm on an attempt to reduce the damage caused by the plant insect.

A dendogram was generated to show the proximity of the HPLC profiles of the metabolites present in the extracts (Figure 3 and Figure 4). Similar samples were grouped together in the same key. It was noticed similarity between PCA and HCA samples. In both, there is a well defined group while G2 (infested and non-infested) were distant between themselves and of the group. The pair of infested and non-infested extracts of G3 was the most similar to each other. The pair of G2 presented greater distinction between themselves since a great distance was observed between them. It was also observeded that the pair of G5 is neither in the same key nor in a close group. Instead, the infested extract of that genotype presented greater similarity with the extract of G3.

Considering the two statistical analyses, the chromatograms and consequently the genotypes were significantly changed when exposed to $S$. frugiperda, compared to the HPLC extract profiles of the same genotype, infested and non-infested. According to Howe \& Jander (2008), alteration in the plants metabolism is connected to changes in their genic expression during the feeding.

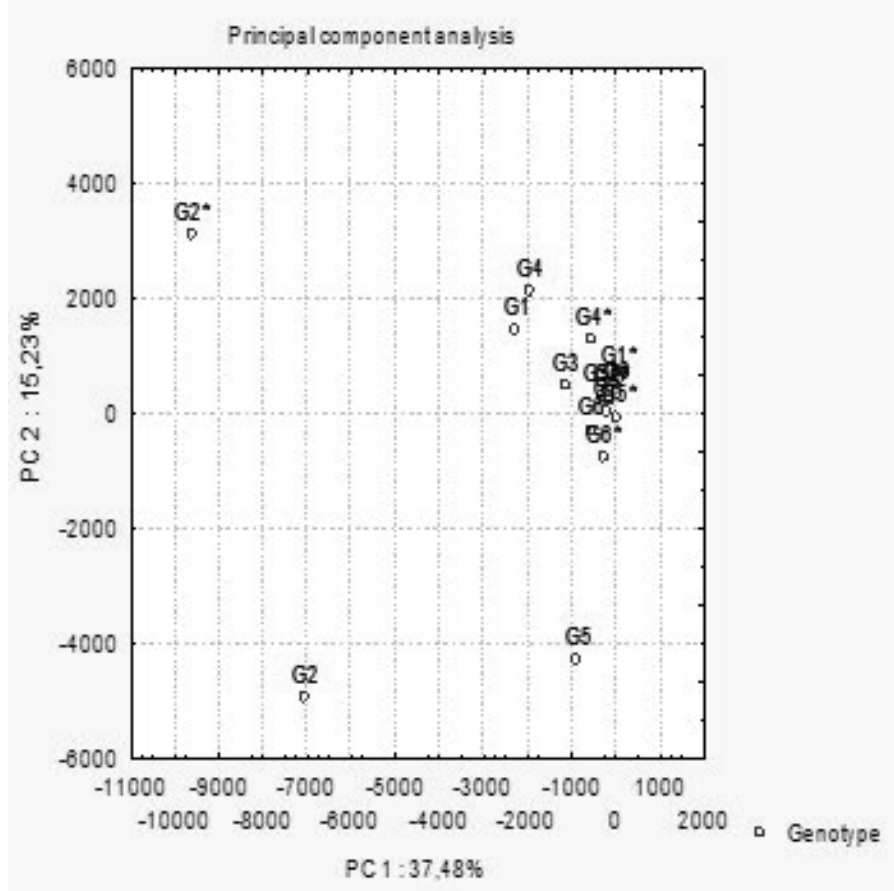

FIGURE 3. Principal Component Analysis of 16 extracts using two components: PC1 (37.48\%) and PC2 (15.23\%). The asterisks mark the infested genotypes. 


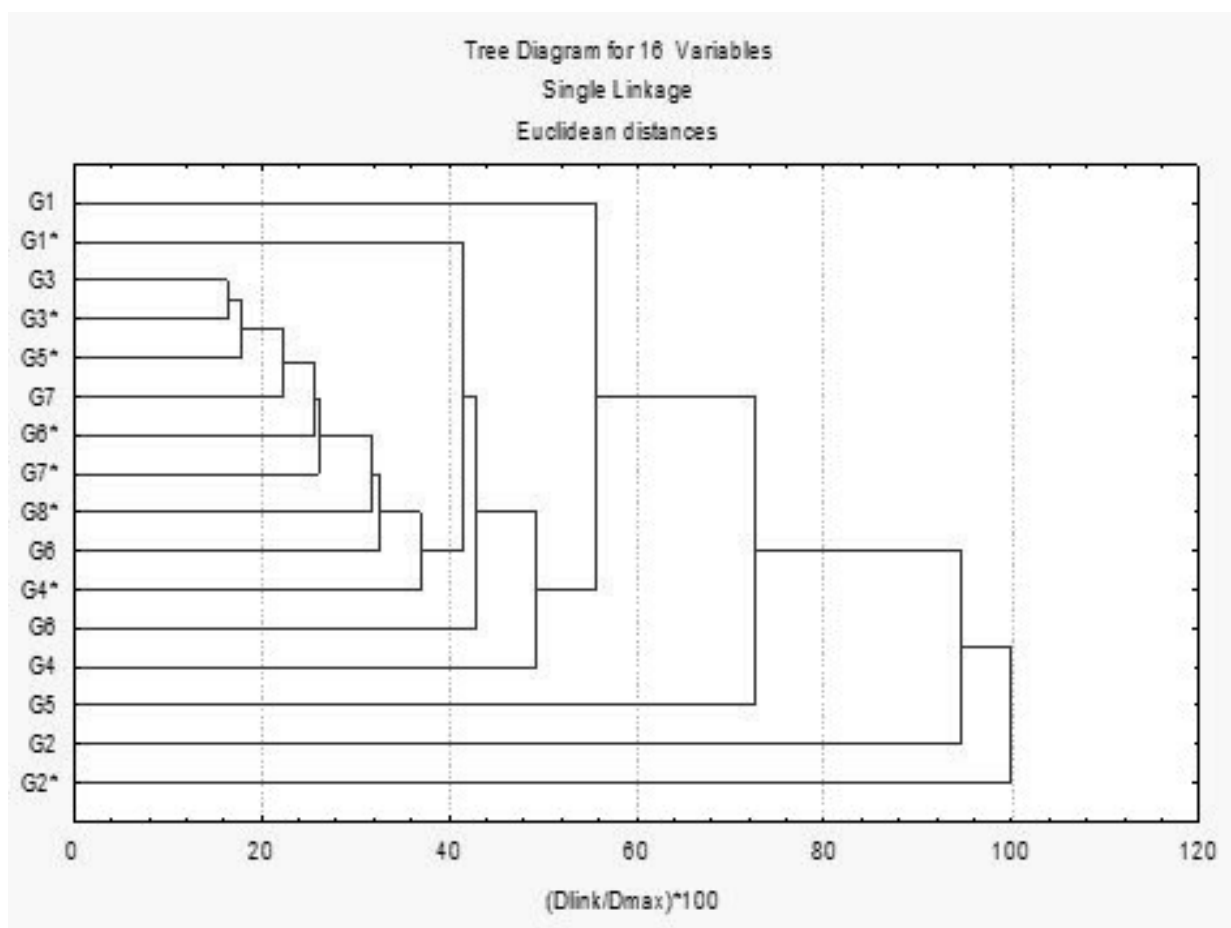

FIGURE 4. Dendrogram of genotypes classification. The asterisks mark the infested genotypes.

\section{Conclusion}

The chlorogenic acid was identified in the eight genotypes analyzed except for not infested Zapalote Chico. The infestation caused alterations in chlorogenic acid levels and in the results of the biological assays with $S$. frugiperda in all studied plants. For the five genotypes (LCMS23-23, MIRT-2Q, LMIRT-2Q, HSCMS23-6LCMS2323 X CMS23-21B, HSMIRT4LMRT2A X LMIRT20B), a reduction of this acid concentration was observed after infestation. For genotype LCMS2321, no statistical difference was observed after infestation and, in one case (L3), an increase of the production of chlorogenic acid occurred after infestation. The concentration of chlorogenic acid could not be directly correlated to toxicity to the fall armyworm.

\section{Acknowledgments}

The authors thank FAPEMIG, EMBRAPA, CNPQ and CAPES (Brazil) for financial support.

\section{References}

ARIAS, R. E. S.; BLANCO, C. A.; PORTILLA, M.; SNODGRASS, G. L.; SCHEFFLER, B. E. First microsatellites from Spodoptera frugiperda (Lepidoptera: Noctuidae) and their potential use for population genetics. Annals of the Entomological Society of America, Lanham, v. 104, p. 576-587, 2011.

AUSTRALIAN GOVERNMENT. The Biology of Zea mays L. SSP mays (maize or corn) Department of Health and Ageing Office of the Gene Technology Regulator, Canberra, p. 
80, 2008. Disponível em: <http://www.ogtr.gov. $\mathrm{au} /$ internet/ogtr/publishing.nsf/content/maize3/\$FILE/biologymaize08_2.pdf $>$. Acesso em 22 mar 2010.

BROOKS, T. D.; BUSHMAN, B. S.; WILLIAMS, W. P., MCMULLEN, M. D.; BUCKLEY, P. M. Genetic Basis of Resistance to Fall Armyworm (Lepidoptera: Noctuidae) and Southwestern Corn Borer (Lepidoptera: Crambidae) LeafFeeding Damage in Maize Source: Journal of Economic Entomology, Lanham, v. 100, p. 1470-1475, 2007.

CAPINERA, J. L. Fall Armyworm, Spodoptera frugiperda (J. E. Smith) (Insecta: Lepidoptera: Noctuidae). Institute of Food and Agricultural Sciences, University of Florida, p6, 2008. Disponível em: $<$ http://edis.ifas.ufl.edu/in255>. Acesso em: 22 mar. 2010.

COSTA, L. P.; SENA, M. R.; GUIMARÃES , P. E. O. de; VIANA , P. A.; PACHECO, C. A. P. Avaliação de linhagens de milho para resistência à lagarta-do-cartucho, Spodoptera frugiperda (J. E. Smith). In: $26^{\circ}$ CONGRESSO NACIONAL DE MILHO E SORGO, Belo Horizonte, 2006. Disponível em: <http://ainfo.cnptia.embrapa.br/digital/ bitstream/item/29779/1/Avaliacao-linhagens. pdf $>$. Acesso em 4 nov 2013.

CUNHA, U. S.; MARTINS, J. F. S.; PORTO, M. P.; GARCIA, M. S.; BERNARDI, O.; TRECHA, C. O.; BERNARDI, D.; JARDIM, E. O.; BACK, E. C. U. Resistência de genótipos de milho para cultivo em várzeas subtropicais à lagarta-do-cartucho Spodoptera frugiperda. Ciência Rural, Santa Maria, v. 38, p. 11251128, 2008.

FARINELLI, R.; FORNASIERI FILHO, D.
Evaluation of damage by Spodopetera frugiperda (J. E. SMITH, 1797) (Lepidoptera: Noctuidae) to maize cultivars. Científica: Revista de Ciências Agrárias, Jaboticabal, v. 34, p. 197-202, 2006.

HOWE, G. A.; JANDER, G. Plant Immunity to Insect Herbivores. Annual Review of Plant Biology, Palo Alto, v. 59, p. 41-66, 2008.

IBANEZ, S.; GALLET, C.; DESPRÉS, L. Plant Insecticidal Toxins in Ecological Networks. Toxins, Basel, v. 4, p. 228-243, 2012.

JOURDIE, V.; ALVAREZ, N.; MOLINA-OCHOA, J.; WILLIAMS, T.; BERGVINSON, D.; BENREY, B.; TURLINGS, T. C. J.; FRANCK, P. Population genetic structure of two primary parasitoids of Spodoptera frugiperda (Lepidoptera), Chelonus insularis and Campoletis sonorensis (Hymenoptera): to what extent is the host plant important? Molecular Ecology, Malden, v. 19, p. 2168-2179, 2010.

LIMA, J. L.; SOUZA, J. C.; MACHADO, J. C.; RAMALHO, M. A. P. Controle genético da exigência térmica para o início do florescimento em milho. Bragantia, Campinas, v. 67, p. 127131, 2008.

NAGOSHI, R. N.; SILVIE, P.; MEAGHER, R. L.; LOPEZ, J.; MACHADO, V. Identification and comparison of fall armyworm (lepidoptera: noctuidae) host strains in Brazil, Texas, and Florida. Annals of the Entomological Society of America, Lanham, v. 100, p. 394-402, 2007. NEGRISOLI Jr., A. S.; GARCIA, M. S.; NEGRISOLI, C. R. C. B. Compatibility of entomopathogenic nematodes (Nematoda: Rhabditida) with registered insecticides for Spodoptera frugiperda (Smith, 1797) (Lepidoptera: Noctuidae) under laboratory conditions. Crop 
Protection, Oxford, v. 29, p. 1-5, 2010.

ROCHA, L. O.; REIS, G. M.; SILVA, V. N.; BRAGHINI, R.; TEIXEIRA, M. M. G.; CORRÊA, B. Molecular characterization and fumonisin production by Fusarium verticillioides isolated from corn grains of different geographic origins in Brazil.

International Journal of Food Microbiology, Amsterdam, v. 145, p. 9-21, 2011.

SÁ, V. G. M.; FONSECA, B. V. C.; BOREGAS, K. G. B.; WAQUIL, J. M. Sobrevivência e Desenvolvimento Larval de Spodoptera frugiperda (J. E. Smith) (Lepidoptera: Noctuidae) em Hospedeiros Alternativos. Neotropical Entomology, Londrina, v. 38, p. 108-115, 2009.

SANTOS, L. M.; REDAELLI, L. R.; DIEFENBACH, L. M. G.; EFROM, C. F. S. Fertilidade e longevidade de Spodoptera frugiperda (J. E. Smith) (Lepidoptera: Noctuidae) em genótipos de milho. Ciência Rural, Santa Maria, v. 34, p. 345-350, 2004.

SILVA, D. M. P.; OLIVEIRA, J. V.; TABOSA, J. N.; BARROS, R.; SANTOS, E. O.; AZEVEDO, S. S. Identificação de fontes de resistência de milho à Spodoptera frugiperda (J. E. Smith, 1797) (Lepidoptera: Noctuidae) em campo. Brazilian Archives of Biology and Technology, Curitiba, v. 43 , p. $345-348,2000$

SILVEIRA, L. C. P.; VENDRAMIM， J. D.; ROSSETTO, C. J. Efeito de Genótipos de Milho no Desenvolvimento de Spodoptera frugiperda (J. E. Smith). Anais da Sociedade Entomológica do Brasil, Jaboticabal, v. 26, p. 291-298, 1997.

SOUSA, E. H. S.; MATOS, M. C. B.; ALMEIDA,
R. S.; TEODORO, A. V. Forest Fragments' Contribution to the Natural Biological Control of Spodoptera frugiperda Smith (Lepidoptera: Noctuidae) in Maize. Brazilian Archives of Biology and Technology, Curitiba, v. 54, p. 755-760, 2011.

STOUT, M. J.; RIGGIO, M. R.; YANG, Y. Direct Induced Resistance in Oryza sativa to Spodoptera frugiperda. Environmental Entomology, Lanham, v. 38, p. 1174-1181, 2009.

VAN DEN BERG, J.; HILBECK, A.; BØHN, T. Pest resistance to Cry1Ab Bt maize: Field resistance, contributing factors and lessons from South Africa. Crop Protection, Oxford, v. 54, p. 154160, 2013.

VIANA, P. A., GUIMARÃES, P. E. O. Maize resistance to the lesser cornstalk borer and fall armyworm in Brazil. In: Proceedings of an International Symposium, p. 112-116, 1997.

VIANA, P. A.; POTENZA, M. R. Avaliação de antibiose e não-preferência em cultivares de milho selecionados com resistência à lagartado-cartucho. Bragantia, Campinas, v. 59, p. 27-33, 2000.

WAQUIL, J. M.; VILLELA, F. M. F.; FOSTER, J. E. Resistência do milho (Zea mays L.) transgênico (bt) à lagarta-do-cartucho, Spodoptera frugiperda (Smith) (Lepidoptera: Noctuidae). Revista Brasileira de Milho e Sorgo, Sete Lagoas, v. 1, p. 1-11, 2002.

XU, J. G.; HU, Q. P.; LIU Y. Antioxidant and DNA protective activities of chlorogenic acid isomers. Journal of Agricultural and Food Chemistry, Washington, v. 60, p. 11625-11630, 2012. 